\title{
Depression is associated with CD4 levels in people living with HIV in Ecuador
}

\author{
Alejandro Checa*, Eliana Navas, Verónica Valencia, and Jessica Alcívar \\ Unidad de Salud Mental, Hospital de Especialidades Eugenio Espejo, Quito, Ecuador
}

\begin{abstract}
Background: HIV can cause neurotoxicity and neuronal apoptosis, hence the importance of neuropathogenesis mechanisms in HIV. People in AIDS phase with CD4 count under 250, may be at greater risk of suffering from depression. Objective: Evaluate whether there is a relationship between T-CD4 lymphocyte count and depression in people living with HIV but have not started antiretroviral treatment. Method: This was a cross-sectional cohort study conducted between October 2020 and January 2021 in the HIV Unit of the Eugenio Espejo Hospital in Quito. A CD4 test was performed, and the Hamilton Depression Scale was used in patients after 1 month of being diagnosed with HIV but before receiving antiretroviral treatment. Results: A total of 108 subjects were recruited, mainly men (79.6\%), of which $82.4 \%$ were between 18 and 45 years old. The subjects in the AIDS phase were $25 \%$ of which $92.6 \%$ presented depression $(p=0.000)$, it was noted that the older the age, the prevalence of depression increases $(p=0.007)$. As for the female sex, it seems to have a risk of practically double with respect to men of suffering from depression $(p=0.005)$. Conclusions: In our cohort study, at PLWH in Ecuador, patients in AIDS phase present a considerable risk of suffering from depression; at the same time, as the age increases, the probability of presenting depression is greater. As well as, female sex is a risk factor. Therefore, the follow-up of these patients is an essential part of care and treatment process.
\end{abstract}

Key words: CD4. HIV. Depression.

\section{Asociación entre conteo de CD4 y depresión en personas que viven con VIH en Ecuador}

\section{Resumen}

Antecedentes: EI VIH puede causar neurotoxicidad y apoptosis neuronal, de ahí la importancia de los mecanismos de su neuropatogénesis, las personas en fase de SIDA con conteo de CD4 inferior a 250 pueden tener mayor riesgo de padecer depresión. Objetivo: Evaluar si existe relación entre el recuento de linfocitos T-CD4 y la depresión en personas viviendo con $\mathrm{VIH}$ en pacientes que no han iniciado tratamiento antirretroviral. Método: Se trata de un estudio de cohorte transversal realizado entre octubre de 2020 y enero de 2021 en la Unidad de VIH del Hospital Eugenio Espejo de Quito. Se realizó una prueba de CD4 y se utilizó la Escala de Depresión de Hamilton en pacientes un mes después de ser diagnosticados con VIH y antes de recibir tratamiento antirretroviral. Resultados: Se reclutaron 108 sujetos, principalmente hombres (79.6\%), de los cuales el 82,4\% tenían entre 18 y 45 años. Los sujetos en fase SIDA fueron 25\% de los cuales $92.6 \%$ presentaron depresión $(p=0.000)$, a mayor edad aumenta la prevalencia de depresión $(p=0.007)$. En el sexo femenino el riesgo parece

\section{Correspondence:}

*Alejandro Checa

E-mail: alcz_11@yahoo.es
Date of reception: 21-04-2021

Date of acceptance: 08-07-2021

DOI: $10.24875 / R M N .21000032$
Available online: $15-11-2021$

Rev Mex Neuroci. 2021;22(6):224-228 www.revmexneurociencia.com 2604-6180/ C 2021 Academia Mexicana de Neurología A.C. Published by Permanyer. This is an open access article under the CC BY-NC-ND license (http://creativecommons.org/licenses/by-nc-nd/4.0/). 
duplicar con respecto a los hombres de padecer depresión $(p=0,005)$. Conclusiones: En nuestro estudio de cohorte, en PLWH, los pacientes en fase SIDA presentan un riesgo considerable de padecer depresión, a medida que aumenta la edad, la probabilidad de presentar depresión es mayor y el sexo femenino es un factor de riesgo. Por tanto, el seguimiento de estos pacientes es una parte fundamental del proceso de atención y tratamiento.

Palabras Clave: CD4. VIH. Depresión.

\section{Introduction}

As shown, people living with HIV tend to experience prolonged episodes of depression throughout their illness, which directly affects adherence to treatment and their quality of life ${ }^{1}$. HIV can cause neurotoxicity and neuronal apoptosis ${ }^{2}$, hence the importance of mechanisms in HIV neuropathogenesis, since pro-inflammatory cytokines/chemokines released by infected macrophages/microglia, excitotoxicity, and oxidative stress are evidenced as the main causes of neuronal injury, in addition to the one directly caused by viral proteins ${ }^{3}$. Traditionally, the histopathological impact of HIV brain infection included widespread reactive astrocytosis, activation of microglia, microglial nodules, and multinucleated giant cells in central white and deep gray matter, monocytoid cell infiltrates, and myelin paleness ${ }^{4}$. The persistence of HIV predicts the dysregulated metabolism of catecholamine precursor amino acids ${ }^{5}$ with a clear incidence in the pathophysiology of depression. Serotonergic neurons play a crucial role in brain function and dysfunction, as in major depressive disorder; however, the complexity of serotonergic projections seriously hinders the elucidation of their precise mechanisms ${ }^{6}$. Therefore, the central nervous system of a patient with HIV would be notably aged in relation to his age group $^{7}$; this neurodegenerative process would be related to the increase in the chances of the appearance of depressive symptoms. This study focuses on the relationship between CD4 T-lymphocyte count and depression, since there is still not enough scientific evidence to clarify whether patients with a CD4 lower than 250 cells/ml (AIDS) present more depressive symptoms in relation to those who are not in the AIDS phase ${ }^{8}$.

\section{Subjects and methods}

This was a cross-sectional cohort study conducted between October 2020 and January 2021 in the HIV Unit of Hospital Eugenio Espejo in Quito, Ecuador. This hospital, one of the largest in Ecuador, is responsible for providing care for at least $10 \%$ of PLWHA nationwide. The study was authorized by the Ethics Committee for Research in Human Beings validated by the Ministry of Public Health of Ecuador. The informed consent of each subject was obtained.

All NAIVE patients who attended the HIV clinic in this period with an HIV diagnosis were invited to participate in the study. A total of 108 subjects were recruited, with a diagnosis of HIV through the third and fourth generation ELISA test with a reactive result, as indicated by the guidelines of the Ministry of Public Health of Ecuador. A CD4 test was performed at the national reference laboratory of the Ministry of Health. After signing the consent form, each one was evaluated using the Hamilton depression scale ${ }^{9}$, which consists of five categories: no symptoms of depression ( $<7$ points), and then mild (8-13 points), moderate (14-18 points), serious (19-22 points), and very serious (> 23 points). The Spanish version of the Hamilton Depression Scale has been previously validated ${ }^{10}$. The evaluation with this scale was carried out one month after diagnosis and before the start of antiretroviral therapy. Subjects with a previous history of depression and psychiatric illness were excluded. The captured data were entered into an electronic database and descriptive statistics, the statistical analysis contemplated a 95\% confidence interval, using Chi-square, for which the SPSS version 23 program was used. In all cases, $p<0.05$ was statistically significant.

\section{Results}

A total of 108 subjects were recruited, mainly men (79.6\%) (Table 1), of which $82.4 \%$ were between 18 and 45 years old. Of the people aged between 46 and 60 years, $63.1 \%$ had mild-to-moderate depression $(n=$ 12), the individuals aged between 31 and 45 years $45.8 \%$ showed some type of depressive symptoms ( $\mathrm{n}$ $=12)(n=22)$. In the 18 to 30 -year-old category, $26.8 \%$ $(n=11)$ had some sign of depression (Table 2). The evaluation with the scale of depression of Hamilton, $58.3 \%(n=63)$ of patients had no depression, and 41.7 $\%(n=45)$ presented some degree of depression. The 
Table 1. Sex

\begin{tabular}{|l|c|c|c|c|}
\hline & Frequency & Percentage & Valid percentage & Accumulated percentage \\
\hline Valid & & & & 79.6 \\
Man & 86 & 79.6 & 79.6 & 100.0 \\
Woman & 22 & 20.4 & 20.4 & \\
Total & 108 & 100.0 & 100.0 & \\
\hline
\end{tabular}

Table 2. Age

\begin{tabular}{|c|c|c|c|c|}
\hline & Frequency & Percentage & Valid percentage & Accumulated percentage \\
\hline Valid & & & 38.0 & 38.0 \\
$18-30$ & 41 & 38.0 & 44.4 & 17.6 \\
$31-45$ & 48 & 44.4 & 100.0 \\
$46-60$ & 19 & 17.6 & 100.0 \\
Total & 108 & 100.0 & \\
\hline
\end{tabular}

Table 3. CD4

\begin{tabular}{|l|c|c|c|c|}
\hline & Frequency & Percentage & Valid percentage & Accumulated percentage \\
\hline Valid & & & & \\
$\quad$ AIDS & 27 & 25.0 & 25.0 & 25.0 \\
No AIDS & 81 & 75.0 & 75.0 & 100.0 \\
Total & 108 & 100.0 & 100.0 & \\
\hline
\end{tabular}

Table 4. Cross table

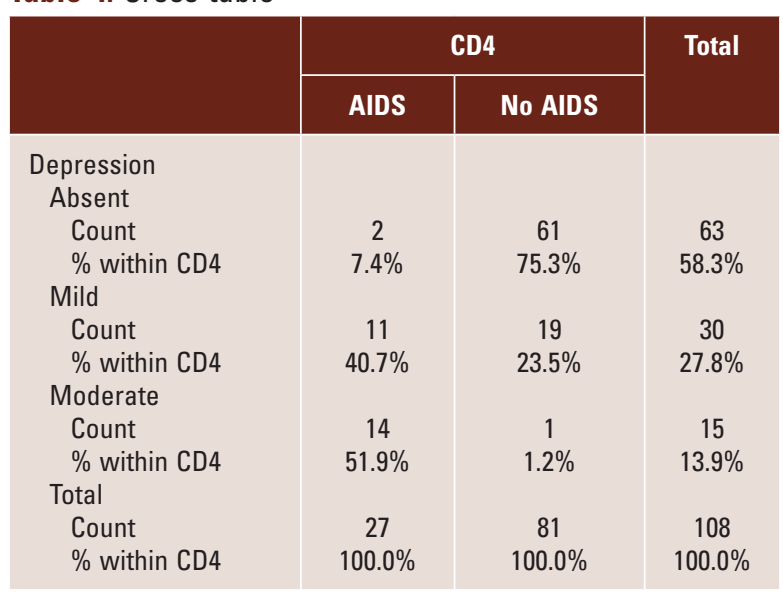

subject considered phase AIDS was $2.5 \%$. Of the subjects in the AIDS phase, $92.6 \%$ manifest depressive symptoms and only $7.4 \%(n=2)$ did not present depression. By contrast of the subjects considered nonAIDS, $75.3(n=61)$ were not positive for depression, a considerably lower number $24.7 \%(n=20)$ scored positive in some measure for depression. As per the women who participated in the study, $68.2 \%$ presented depression $(n=15)$ (Tables 3 and 4$)$.

It was found that there is a relationship between depression and age $(p=0.007)$. Similarly, there is a positive association between sex and depression $(p=0.005)$. Finally, there is a highly significant association between patients in the AIDS phase and depression $(p=0.000)$ (Table 5).

\section{Discussion}

In the present study, it was found that around $40 \%$ of PLWHA treated at the HIV Clinic at the Eugenio Espejo Hospital in Quito, Ecuador had some degree of depression, much more than previously reported in a similar population in Ecuador ${ }^{11}$. It is important to mention that mental health is a generally neglected area among health services in Ecuador, which leads to failure in the diagnosis of psychiatric problems among the general population, not to mention among PLWHA. Most of the subjects, who are in the AIDS phase in this study, present symptoms of depression in line with the few studies carried out in reference to this topic ${ }^{12}$, which shows a possible role of the neurotrophic factor derived from the brain in the symptoms of depression and other aspects of the state of mind that until now have been superficially studied. It has also been noted that there are more positive cases of depression as age increases, these results are in accordance with other studies carried out ${ }^{13}$. Age appears to be a predictor of comorbidity. The female sex also seems to be associated with a higher incidence of 
Table 5. Chi-square tests

\begin{tabular}{|l|c|c|c|}
\hline & Value & gl & $\begin{array}{c}\text { Asymptotic } \\
\text { significance } \\
\text { (bilateral) }\end{array}$ \\
\hline Pearson's Chi-square & $55,539^{\text {to }}$ & 2 & 0.000 \\
\hline Likelihood ratio & 56,951 & 2 & 0.000 \\
\hline $\begin{array}{l}\text { Linear by linear } \\
\text { association }\end{array}$ & 53,710 & 1 & 0.000 \\
\hline N of valid cases & 108 & & \\
\hline
\end{tabular}

depression in PLWHA, as verified in other studies ${ }^{14}$, studies in Spanish-speaking America in this regard are scarce, so this mood disorder could be related to other variables. Lower levels of brain-derived neurotrophic factor BDNF were associated with AIDS diagnosis and CD4 count, but not with viremia or duration of infection, which, in turn, has a direct correlation with depression ${ }^{12}$ confirming our premise that CD4 levels are directly related to depression. Studies conducted in the United States show that age, sex, race, baseline CD4 count, and viral load are significant factors associated with increased risk of mental illness ${ }^{15}$, which supports our findings. While we recognize that the screening tools used for depression may have increased the number of diagnosed patients, we believe that the criteria used allowed us to select the most clinically significant cases. Furthermore, another limitation was that the subjects were recruited from only one center, although one of the largest, and there was no control group due to national guidelines for the care of PLWHA. In any case, our results support that patients in the AIDS phase have a higher risk of suffering from depression, as well as gender and age are factors that contribute to both the frequency and the severity of depression cases among PLWHA in Ecuador.

\section{Conclusions}

In our cohort study, in PLWHA in Ecuador, patients in the AIDS phase have a considerable risk of suffering from depression, in the same way, at an older age; there is a greater probability of presenting depression as well as being a female sex a risk factor. Therefore, the follow-up of these patients is essential as part of the care and treatment process.

\section{Acknowledgments}

We thank Malena Camacho, internist at Hospital de Especialidades Eugenio Espejo and Violeta Zurita for their collaboration and work in the editorial process of this publication.

\section{Funding}

The authors declare that the research was funded by the Mental Health Unit of the Hospital de Especialidades Eugenio Espejo and no contribution of any kind has been received from any other entity.

\section{Conflicts of interest}

The authors declare that they have no conflict of interest.

\section{Ethical disclosures}

Protection of human and animal subjects. The authors declare that no experiments were performed on humans or animals for this study.

Confidentiality of data. The authors declare that they have followed the protocols of their work center on the publication of patient data.

Right to privacy and informed consent. The authors declare that no patient data appear in this article.

\section{References}

1. Chi P, Zhao S, Zhang C, Li X, Guo Y, Lin X, et al. Effects of psychosocial interventions on children affected by parental HIV/AIDS: a meta-analysis on depression and anxiety. BMC Public Health. 2019; 19:1572.

2. Ru W, Liu X, Bae C, Shi Y, Walikonis R, Mo Chung J, et al. Microglia mediate HIV-1 gp120-induced synaptic degeneration in spinal pain neural circuits. J Neurosci. 2019;39:8408-21.

3. Fields JA, Ellis RJ. HIV in the cART era and the mitochondrial: immune interface in the CNS. Int Rev Neurobiol. 2019;145:29-65.

4. Cantres-Rosario YM, Ortiz-Rodríguez SC, Santos-Figueroa AG, Plaud M Negron K, Cotto B, et al. HIV infection induces extracellular cathepsin B uptake and damage to neurons. Sci Rep. 2019;9:8006

5. Chahine A, Koru-Sengul T, Feaster DJ, Dilworth SE, Antoni MH, Klatt N, et al. Blue monday: co-occurring stimulant use and HIV persistence predict dysregulated catecholamine synthesis. J Acquir Immune Defic Syndr. 2021;86:353-60.

6. Nagayasu K. Elucidation of the role of dorsal raphe serotonergic neurons in mood regulation using pharmacological and viral vector-based approaches. Yakugaku Zasshi. 2017;137:341-6.

7. Dong $\mathrm{H}, \mathrm{Ye} X$, Zhong L, Xu J, Qiu J, Wang J, et al. Role of FOXO3 activated by HIV-1 tat in HIV-associated neurocognitive disorder neuronal apoptosis. Front Neurosci. 2019;13:44.

8. Agus DF, Effendy E, Camellia V. Screening of anxiety and depression related CD4 count of people living with HIV/AIDS with anti-retroviral in medan, Indonesia. Open Access Maced J Med Sci. 2019;7:2590-4.

9. Park SC, Jang EY, Kim JM, Jun TY, Lee MS, Kim JB, et al. Clinical validation of the psychotic depression assessment scale, hamilton depression rating scale-6, and brief psychiatric rating scale-5: results from the clinical research center for depression study. Psychiatry Investig. 2017; $14: 568-76$ 
Rev Mex Neuroci. 2021;22(6)

10. Bobes J, Bulbena A, Luque A, Dal-Ré R, Ballesteros J, Ibarra N, et al. Evaluación psicométrica comparativa de las versiones en español de 6 , 17 y 21 ítems de la Escala de valoración de Hamilton para la evaluación de la depresión. Med Clin. 2003;120:693-700.

11. Pérez-Rodríguez I, Pérez-Salgado D, Compeán-Dardón MS, Staines-Orozco MG, Ortiz-Hernández L. Efectos secundarios del tratamiento antirretroviral y apego en pacientes con $\mathrm{VIH}$ de dos instituciones públicas. Med Interna Méx. 2016:32:396-406.

12. Woods SP, Babicz M, Shahani L, Colpo GD, Morgan EE, Teixeira AL. Brain-derived neurotrophic factor (BDNF) is associated with depressive symptoms in older adults with HIV disease. J Neurovirol. 2020;27:70-9.
13. Cabrera DM, Diaz MM, Grimshaw A, Salvatierra J, Garcia PJ, Hsieh E. Aging with HIV in Latin America and the Caribbean: a systematic review. Curr HIV/AIDS Rep. 2021;18:1-47.

14. Girma D, Assegid S, Gezahegn Y. Depression and associated factors among HIV-positive youths attending antiretroviral therapy clinics in Jimma town, Southwest Ethiopia. PLoS One. 2021;16:e0244879.

15. Yang X, Zhang J, Chen S, Weissman S, Olatosi B, Li X. Comorbidity patterns among people living with HIV: a hierarchical clustering approach through integrated electronic health records data in South Carolina. AIDS Care. 2021;33:594-606. 